\title{
MENGEMBANGKAN HOBI MASAK MENJADI BISNIS F DAN B DISAAT COVID-19
}

\author{
Sawukir, Budi Syamtoro, Hestu Nugroho Warasto, \\ Muhamad Nurhamdi, Dana \\ Universitas Pamulang \\ dosen02319@unpam.ac.id,dosen02332@unpam.ac.id,dosen01844@unpam.ac.id, \\ dosen02484@unpam.ac.id,dosen02224@unpam.ac.id
}

\begin{abstract}
In Community Service (PKM) activities, we collaborate with SMPN 12 South Tangerang, which is located in the Kec. Pondok Aren, South Tangerang City, Banten Province. As for the objects in this service are all teachers who teach at SMPN 12 South Tangerang. In this activity, we provide counseling and motivation to educators at SMPN 12 South Tangerang to develop a hobby of cooking into a business opportunity for $F$ and $B$ during the current Covid-19 so that educators get additional income to meet their needs. The results of this dedication show that most of the teaching staff have a hobby of cooking and during the Covid-19 pandemic, educators in the South Tangerang Junior High School 12 have a great interest in developing their cooking hobby to become a Food \& Beverage business as additional income to cover their needs. household during this Covid-19.
\end{abstract}

Keywords: PKM, Food, and Beverage, Cooking Hobby

\begin{abstract}
ABSTRAK
Dalam kegiatan Pengabdian Kepada Masyarakat (PKM), kami melakukan kerja sama dengan SMPN 12 Tangerang Selatan yang berada didaerah Kec. Pondok Aren, Kota Tangerang Selatan, Provinsi Banten. Adapun yang menjadi objek dalam pengabdian ini adalah seluruh Guru yang mengajar dilingkungan SMPN 12 Tangerang Selatan. Dalam kegiatan ini kami memberikan penyuluhan dan motivasi kepada para tenaga pendidik SMPN 12 Tangerang Selatan untuk mengembangkan hobi masak menjadi peluang bisnis $\mathrm{F}$ dan B disaat Covid-19 saat ini agar para tenaga pendidik mendapatkan pendapatan tambahan untuk memenuhi kebutuhan. Hasil dari pelaksanaan pengdian ini menunjukan bahwa sebagian besar tenaga pendidik memiliki hobi memasak dan selama pandemic Covid-19 ini tenaga pendidik yang berada dilingkungan SMPN 12 Tangerang Selatan memiliki minat yang besar untuk mengembangkan hobi masaknya untuk dijadikan bisnis Food \& Beverage sebagai tambahan pendapatan untuk menutupi kebutuhan rumah tangga disaat Covid-19 ini.
\end{abstract}

Kata kunci : PKM, Food and Beverage, Hobi Masak 


\section{A. PENDAHULUAN}

Apakah anda memiliki hobi atau keterampilan yang saat ini hanya dilakukan atau digunakan di waktu luang? Meskipun anda mungkin menganggap itu hanya cocok sebagai hobi, ada kemungkinan anda dapat menghasilkan uang dan mengubah bakat serta hobi tersebut menjadi suatu bisnis yang menguntungkan. Namun semua itu tentu saja jika anda mengetahui bagaimana cara-caranya. Saya akan membahas tentang bagaimana mengubah hobi dan keterampilan menjadi suatu bisnis yang menguntungkan. Melakukan pekerjaan yang sesuai dengan passion kita tentu saja akan jauh lebih menyenangkan dari pada melakukan pekerjaan yang monoton, membosankan, dan tidak sesuai dengan minat kita. Hobi yang berpotensi untuk dijadikan bisnis contohnya misalkan adalah hobi memasak, membuat kue, membuat kerajinan tangan, desain grafis, olah raga seperti renang, basket, dan apa pun yang secara harafiah dapat memberikan nilai bagi orang lain. Masalahnya adalah banyak dari kita takut untuk mencoba dan berusaha, bahkan walaupun kita sadar bahwa kita memiliki keterampilan yang dapat dipasarkan, kita tetap tidak mencobanya karena berbagai anggapan yang memandang rendah pekerjaan yang berdasarkan hobi dan ketakutan akan gagal dan dipandang sebelah mata. Hal ini bisa menjadi penghambat bagi seorang individu untuk berkembang dan memaksimalkan potensi mereka.

Mencoba berbisnis dari hobi memang tidaklah mudah, namun dengan persiapan dan perencanaan yang baik, anda bisa menikmati hasil positif. Berikut ini adalah beberapa tips yang dapat dicoba:

1. Membuat Rencana Bisnis dari Hobi

Pada awal mula untuk menjadikan hobi kita sebagai sebuah bisnis beberapa jenis hobi membutuhkan persiapan dalam bentuk modal secara finansial namun sebagian hobi lainnya tidak. Apabila hobi kita adalah hobi yang membutuhkan modal finansial di awal, anggap saja untuk membuat promosi masakan, iklan kue-kue buatan kita, contoh produkproduk kerajinan tangan etnik yang akan kita jual, maka kita harus merencanakan kira-kira berapa banyak modal yang kita butuhkan untuk tahap awal bisnis kita tersebut. Apabila status finansial kita cukup memadai tentunya kita tidak perlu pusing memikirkan modal awal tersebut. Namun apabila kemampuan finansial kita kurang memadai maka kita harus mempersiapkan jauh-jauh hari untuk mendanai bisnis kita tersebut. Kita harus menabung, mengumpulkan uang dari pekerjaan lain yang saat ini kita jalani (yang mungkin suatu saat ingin kita tinggalkan karena terasa begitu melelahkan dan tidak sesuai dengan passion kita).

2. Melakukan Promosi di Awal Bisnis

Ketika kita memulai hobi bisnis kita tentu saja orang-orang masih banyak yang belum mengetahui tentang bisnis kita tersebut. Maka disinilah kita perlu mempromosikan bisnis tersebut. Untuk bisnis dalam bentuk barang, tidak ada salahnya jika kita memberikan diskon besar di awal penjualan agar konsumen tertarik untuk mencoba dan mengenal produk kita. Untuk bisnis dalam bentuk jasa, kita bisa memberikan free trial atau kelas gratis bagi para calon konsumen kita.

3. Memaksimalkan Waktu untuk Bisnis Tersebut

Ketika kita serius pada suatu bisnis maka kita harus meluangkan waktu dan memberikan perhatian lebih pada hobi berbasis bisnis tersebut. Jika saat ini kita sedang sekolah atau memiliki pekerjaan full time, maka kita harus mengusahakan bagaimana agar ada waktu untuk bisnis tersebut, ntah dengan bangun lebih pagi atau mengurangi waktu santai dan jalan-jalan. 


\section{Meng-Online kan Bisins Tersebut}

Agar konsumen lebih mudah mengenali dan mendapatkan informasi tentang produkproduk kita, maka kita perlu mempromosikannya secara online. Apabila bisnis kita dalam bentuk barang kita perlu membuat website atau akun media sosial khusus untuk produkproduk yang kita jual. Disini tampilan produk, tata cara pemotretan, dan keterangan tentang produk harus diperhatikan dengan baik. Apabila bisnis kita dalam bentuk jasa maka kita perlu menjaga citra diri kita baik di dunia maya maupun di dunia nyata. Jangan sampai calon konsumen mengurungkan niat menggunakan jasa kita karena merasa ill-feel dengan kata-kata dan perilaku kita yang tidak sopan.

5. Menjalin Networking

Salah satu kunci kesuksesan suatu bisnis adalah apabila orang atau bisnis tersebut mampu menjalin kerja sana dan hubungan baik dengan mitra kerja dan konsumen. Selalu bayar supplier tepat waktu, jaga kualitas produk, jangan segan untuk bertegur sapa dan memberikan ucapan selamat pada saat hari raya, semuanya itu adalah hal-hal yang terlihat remeh namun penting untuk menjaga hubungan baik dengan mitra kerja dan konsumen.

6. Memperlakukan Hobi Sebagai Pekerjaan

Apabila kita sudah serius untuk menjadikan hobi tersebut sebagai suatu bisnis. Maka kita harus melihat hobi tersebut sebagai sebuah pekerjaan. Kita harus memikirkan bagaimana cara mengembangkan produk dan jasa yang kita jual. Apabila produk tersebut dalam bentuk barang, maka keluarkanlah inovasi-inovasi terbaru, pelajari pasaran konsumen, apa yang mereka butuhkan, apa yang mereka inginkan, bagaimana daya beli konsumen mayoritas. Apabila produk tersebut dalam bentuk jasa, maka tingkatkan kemampuan anda, ikutlah kursus-kursus tambahan atau seminar-seminar yang mampu mendongkrak nilai jual anda. Dan terakir tentu saja kita harus belajar dari kegagalan dan pengalaman masa lalu. Teruskan yang baik dan hilangkan yang buruk. Semoga artikel ini bermanfaat.

Makanan adalah kebutuhan mendasar bagi kehidupan di planet ini. Biasanya, orang menyebut bisnis makanan dan minuman dengan istilah bisnis $\mathrm{F} \& \mathrm{~B}$, bisnis Food and Beverages. Pebisnis $\mathrm{F} \& \mathrm{~B}$ terdiri dari berbagai macam golongan pengusaha, dari mahasiswa sampai pengusaha yang sudah 'beken'. Keuntungan yang menjanjikan dan target pasar yang banyak, membuat bisnis ini digemari. Di Asia Pasifik, pendapatan di segmen Makanan \& Minuman mencapai US \$ 44.176 juta pada tahun 2018 dan diperkirakan akan menunjukkan tingkat pertumbuhan tahunan (CAGR 2018-2023) sebesar $10,8 \%$, menghasilkan volume pasar sebesar US \$ 73.888 juta pada tahun 2023 ( sumber: Statista)

Setiap wirausahawan tersebut memiliki impian untuk membangun bisnis yang tahan lama dan sukses. Iya tidak? Semua orang ingin menjadi besar dan diingat untuk membentuk sesuatu yang istimewa. Tetapi hanya beberapa dari kita yang benar-benar berusaha melakukannya. Statistik menunjukkan bahwa lebih dari 90 persen pemula tidak bertahan lebih dari 3 tahun. Apakah beberapa pengusaha sukses yang menjadikannya memiliki kesamaan besar? Tentu saja. Belajar dan menerapkan dari mereka tidak menjamin Anda berjalan menuju kesuksesan tetapi pasti meningkatkan kemungkinan.

Aturan dasar untuk seorang wirausaha adalah konstan tidak peduli apa pun bisnisnya termasuk F \& B. Itu merupakan suatu keharusan bagi wirausahawan untuk memiliki visi yang tidak goyah dan kuat. Motivasi untuk memulai bisnis dapat berasal dari aliran yang berbeda untuk orang yang berbeda. Saat memulai sesuatu dalam F \& B, langkah pertama adalah benar-benar jelas dengan rencana bisnis. Setiap bisnis perlu melayani beberapa tujuan akhir dari pelanggan dan sangat penting untuk mengidentifikasi hal yang sama. F \& B adalah industri besar dengan berbagai segmen produk dan layanan yang digabungkan dengan medium penjualan yang tak ada habisnya. 
Penting untuk mengidentifikasi ceruk Anda sendiri dan memastikan strategi dan rencana bisnis ditujukan untuk memenuhi kebutuhan pasar tertentu. Ini berarti sejumlah besar upaya harus dimasukkan ke dalam riset pasar awal dan menggabungkannya dengan analisis terperinci tentang kekuatan dan kemampuan Anda sebagai wirausahawan dan sumber daya Anda. Pada setiap saat, nilai riil bisnis Anda hanya akan sebanding dengan nilai yang ditambahkan oleh usaha Anda ke pasar. Jadi, penting untuk tidak melupakan inti bisnis Anda, dan terus menerus menyisihkan waktu, tenaga, dan sumber daya Anda untuk meningkatkannya. Misalnya, jika Anda memulai sebuah restoran, kualitas makanan dan layanan adalah inti Anda dan mempertahankan konsistensi yang sama adalah faktor penting yang menentukan keberhasilan atau kegagalan bisnis jangka panjang. Oleh karena itu, Anda harus memastikan bahwa bisnis Anda berpedoman teguh terhadap SOP.

Membangun sebuah bisnis dari hobi memasak merupakan hal yang sangat tepat. Dimulai dari menyukai memasak kemudian Anda tidak hanya berdiam diri saja. Anda berani mengambil langkah yang sangat bagus untuk memulai bisnis dari hobi memasak tersebut. Membayangkan saja pasti Anda bisa senang sekali berbisnis yang sesuai dengan hobi. Saat menjalankan bisnis pasti tidak akan terasa berat karena sama saja Anda menyalurkan hobi diwaktu luang sambil berbisnis. Bisnis makanan yang dijalankan dalam lingkungan masyarakat memang sangat banyak. Berbagai macam bisnis kuliner yang selalu memanjakan para pecinta makanan sangat sukses. Anda juga bisa membuka bisnis makanan tersebut yang lebih enak, bervariasi dan tentunya memperhatikan kualitas rasa masakannya sangat lezat. Segera wujudkan bisnis dari hobi memasak dengan melihat beberapa peluang bisnis makanan yang sangat laku di pasara

\section{B. METODE PELAKSANAAN KEGIATAN} meliputi :

Adapun tahap-tahap yang kami lakukan dalam Pengabdian Kepada Masyarakat

1. Survei awal, pada tahap ini dilakukan survei ke lokasi SMPN 12 Tangerang Selatan.

2. Setelah survei maka ditetapkan waktu pelaksanaan dan sasaran peserta kegiatan

3. Penyusunan bahan/materi pelatihan yang meliputi: slide dan makalah untuk kegiatan tentang pengembangan hobi masak menjadi bisnis $\mathrm{F}$ dan $\mathrm{B}$

4. Tahap Pelaksanaan

Permasalahan yang ada bahwa para jamaah yang berada di SMPN 12 Tangerang Selatan masih belum memahami tentang hobi masak bisa menjadi peluang bisnis $\mathrm{F}$ dan $\mathrm{B}$. Dengan adanya pelatihan dan penyuluhan di harapkan para tenaga pendidik SMPN 12 Tangerang selatan mampu membuka bisnis makanan atau minuman dan akhirnya mendapatkan keuntungan.

\section{HASIL DAN PEMBAHASAN}

Dalam pengabdian kepada masyarakat ini adalah kami selaku dosen Unpam memberikan penyuluhan tentang peluang usaha yang berasal dari hobi memasak di saat Covid-19 kepada para tenaga pendidik di SMPN 12 Tangerang Selatan. Terlaksananya kegitan ini adalah kami kerjasama dalam melaksanakan kegiatan ini yaitu dengan bekerja sama dengan SMPN 12 Tangerang Selatan. Sebelum melakukan kegiatan pengabdian kepada masyarakat di SMPN 12 Tangerang Selatan terlebih dahulu kami melakukan survey apa saja yang menjadi permasalahan yang dihadapi oleh para tenaga pendidik disaat covid-19 ini di bantu oleh bapak Drs. Nofiardi selaku Kepala Sekolah SMPN 12 Tangerang Selatan. 
Tahap Pelaksanaan Tahap ini kami memberikan penyuluhan kepada para tenaga pendidik SMPN 12 Tangerang Selatan untuk mengembangkan hobi masak menjadi peluang bisnis $\mathrm{F}$ dan B disaat Covid-19 saat ini agar para tenaga pendidik mendapatkan pendapatan tambahan untuk memenuhi kebutuhan disaat Covid-19. Mengacu pada identifikasi permasalahan tersebut, maka solusi yang akan kami berikan untuk membantu memecahkan permasalahan yang adalah;.

1. Memberikan masukan peluang usaha kepada para tenaga pendidik di lingkunganSMPN 12 Tangerang Selatan dari hobi memasak..

2. Memberikan pelatihan stategi pemasaran bisnis F dan B kepada para tenaga pendidik di lingkungan SMPN 12 Tangerang Selatan agar mampu bersaing dengan pembisnis lain.

3. Memberikan pelatihan untuk memulai usaha bisnis $\mathrm{F}$ dan $\mathrm{B}$ untuk para tenaga pendidik di SMPN 12 Tangerang Selatan.
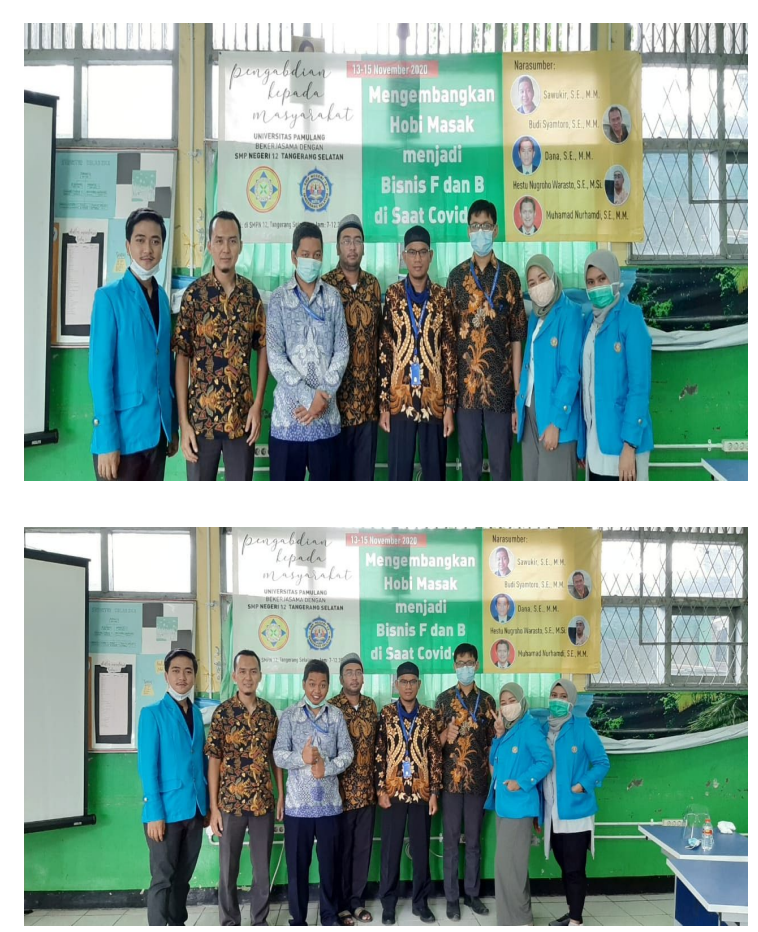
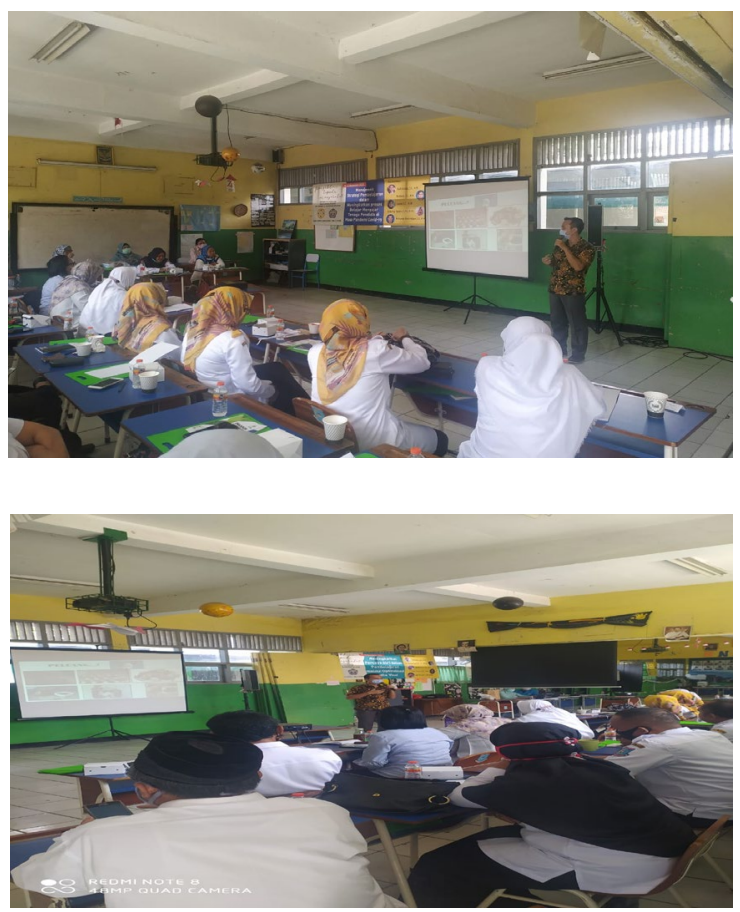

Gambar 1. Photo Kegiatan PKM

\section{KESIMPULAN DAN SARAN}

\section{Kesimpulan}

Kesimpulan yang di dapat dalam laporan pengabdian kepada masyarakat ini adalah Peluang usaha disaat Covid-19 sangatlah penting untuk menambah pendapatan, salah satunya bisnis F dan B.

\section{Saran}

Berdasarkan kegiatan pengabdian kepada masyarakat yang dilakukan di SMPN 12 Tangerang Selatan di harapkan dapat memberikan masukan peluang usaha kepada para tenaga pendidik di linkungan SMPN 12 Tangerang Selatan dan diharapkan para tenaga pendidik di SMPN 12 Tangerang Selatan mempunyai bisnis tambahan di luar menjadi tenaga pendidik. 


\section{DAFTAR PUSTAKA}

https://www.paper.id/blog/bisnis/food-and-beverage-fnb/

https://www.beepos.id/blog/7-hal-yang-perlu-disiapkan-sebelum-memulai-usaha-fb/

https://www.talenta.co/blog/insight-talenta/pengertian-fb-service-modern-serta-jenis-jenistrennya/\#: :text=Industri\%20Food $\% 20 \% 26 \% 20$ Beverage $\% 20(\mathrm{~F} \% 26 \mathrm{~B})$,poros $\% 20 \mathrm{bisni}$ snya $\% 2 \mathrm{C} \% 20$ termasuk $\% 20 \mathrm{~F} \% 26 \mathrm{~B} \% 20$ service.

https://www.covid19.go.id/

https://ukirama.com/en/blogs/10-strategi-bisnis-food-beverage-kuliner-agar-customer-datangke-toko-

anda\#: : :text=Bisnis\%20Food $\% 20$ and $\% 20$ Beverage $\% 20(\mathrm{~F} \% 26 \mathrm{~B}$, kebutuhan $\% 20 \mathrm{yang} \%$ 20 tidak\%20pernah\%20terganti.

https://www.wartaekonomi.co.id/read204976/apa-itu-bisnis-fb-berikut-3-tips-untuk-suksesmenjalaninya.html

https://setkab.go.id/menkes-terbitkan-keputusan-psbb-untuk-kab-kota-bogor-kota-depokdankab-kota-bekasi/ 15. www.covid19.go.id

Jurnal.id (2019, Mare 12). Retrieved from https://www.jurnal.id: https://www.jurnal.id/id/blog/strategi-bisnis-untuk-bersaing-di-era-digital/

Peraturan Gubernur Nomor 27 Tahun 2020 tentang Pedoman PSBB

Surat Edaran Nomor 3 Tahun 2020 tentang Pencegahan COVID-19 pada Satuan Pendidikan;

Surat Edaran dari Menteri Pendidikan dan Kebudayaan Nomor: 36962/MPK.A/HK/2020 tertanggal 17 Maret 2020 tentang Pembelajaran secara Daring dan Bekerja dari Rumah dalam rangka Pencegahan Penyebaran Corona Virus Disease (Covid-19);

Surat Edaran Nomor: 302/E.E2/KR/2020 tentang Masa Belajar Penyelenggaraan Pendidikan; 